\title{
Plastic in blood and wine
}

\author{
Shaun R. McCann $\mathbb{1}^{1}$
}

Received: 16 August 2020 / Revised: 21 August 2020 / Accepted: 27 August 2020 / Published online: 11 September 2020

(c) The Author(s), under exclusive licence to Springer Nature Limited 2020

\section{Blood is a very special juice}

Mephistopheles in Johann Wolfgang van Goethe's (1749-1832) Faust.

Faust signed his now infamous pact with Mephistopheles with a drop of his own blood but, in spite of tumultuous events, he eventually ends up in heaven. In the 17th century William Harvey's description of the circulation of the blood opened a floodgate of scientific research and discovery. It should be remembered however that Harvey was preceded by many figures including Vesalius, Colombo, Ibn-al Nafis, and Erastratus (304-250 BC) [1]. The ancient Chinese understood that blood circulated around the body. However, although blood has fascinated man for millennia, the widespread use of blood transfusion is a relatively recent event.

In the latter half of the 17th century the English, mostly through Richard Lower, and members of the Royal Society, and the French, through Jean-Baptiste Denys and the French Academy of Science, were in constant competition about blood transfusion. Unfortunately, after a series of notorious experiments involving animal-to-human transfusions, Pope Innocent XI banned the practise and blood transfusion went into decline. One hundred and fifty years later a Scottish obstetrician, James Blundell, sometimes referred to as 'the father of modern blood transfusion', performed human-to-human blood transfusions for postpartum haemorrhage [2].

Although blood groups were elucidated, and the mysteries of blood clotting began to be unravelled in the late 19th and early 20th centuries, it was really during the Spanish Civil War that blood transfusion to large numbers

Shaun R. McCann

shaunrmccann@gmail.com

1 University of Dublin Trinity College, Dublin, Ireland of casualties, civilian and military, became widespread [3]. Blood transfusion and the pioneering work of Edwin $\mathrm{J}$. Cohn saved many lives during World War II. Blood and blood products were administered from glass bottles, which were heavy, difficult to transport and expensive to make. Storage of large numbers of glass bottles also created a logistical problem.

The use of plastic for transfusion of blood and blood products changed everything. The term plastic usually refers to a synthetic high molecular mass substance made of organic polymers derived from petrochemicals. The world's first fully synthetic plastic was Bakelite invented in New York in 1907, and the development of polyamide (nylon) by the DuPont corporation eventually led to the manufacture of nylon stockings. Although a lot of manufacturing of nylon stockings was diverted into the manufacture of parachutes, some people believe that the success of the American army in Italy during World War II was, to some extent, due to the fact that GIs gave presents of nylon stockings to Italian girls!

However, it was the Korean War that introduced plastic bags into blood transfusion. Carl W. Walter, a surgeon at the Peter Bent Brigham Hospital at Harvard Medical School, with his colleague William Murphy Jr designed the first polythene blood collection bag which had two plastic tubes: one to give blood to the recipient and the other to collect blood from the donor [4]. The use of these bags was tested extensively during the Korean War; however, it was not until the 1970s that plastic bags came into widespread use in the UK. They are now used world-wide (Fig. 1).

It is hard to imagine modern medicine without the use of plastic. We collect bone marrow into plastic bags (Fig. 2), use plastic bags to administer saline and many other agents and drugs, and even use disposable plastic medical instruments. In HSCT, we use plastic bags to administer hyperalimentation. However, although plastic has contributed greatly to medical practise, the use of single-use plastics has caused immense ecological damage, and the search for reusable or recyclable plastic is warranted immediately. 
During the Covid-19 pandemic the use of personal protective equipment (PPE) has come into sharp focus. Undoubtedly helpful in protecting front-line workers in medical settings, their use has raised some ecological questions. Anna Gross, writing in the weekend Financial Times [5] recently, points out that single-use PPE are undesirable, adding to the plastic waste phenomenon, and Professor Jodi Schermann at Yale university, points out that prior to the 1980s, most PPEs were reusable.

Are plastics involved in the wine industry? Yes. Fermentation tanks can be made of fibreglass (fibre-reinforced

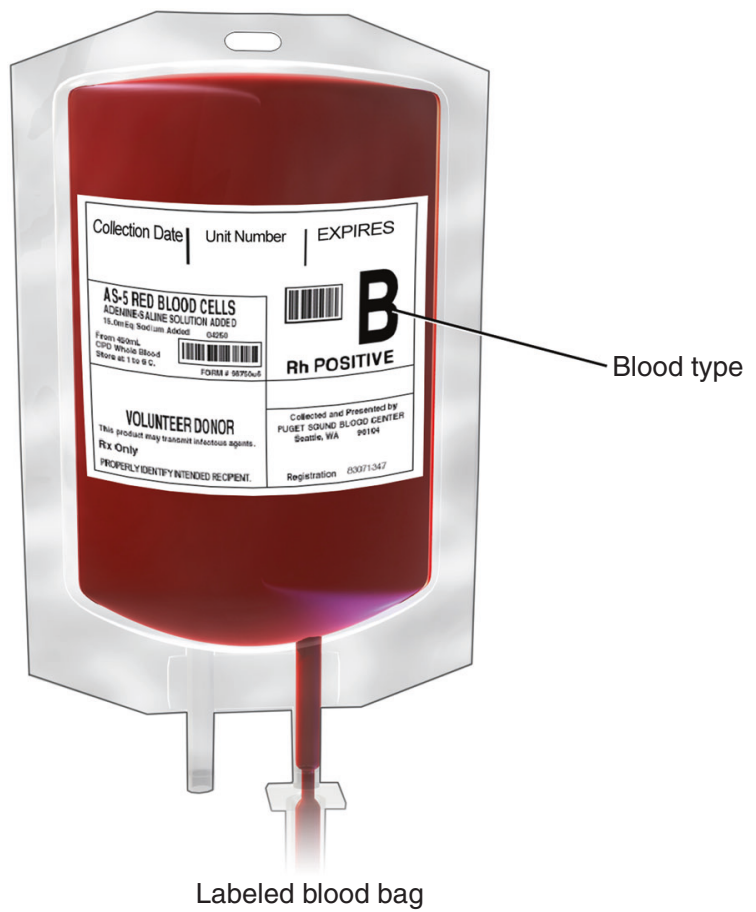

Fig. 1 A plastic bag for blood transfusion. Packed red cells for transfusion in a plastic bag we all know so well. plastic) or epoxy resin (polyepoxides), reactive prepolymers and polymers containing epoxide groups (Fig. 3). Cement fermentation tanks, used since Roman times, have come back into fashion. Many are lined with epoxy resin although some rely on a very smooth cement finish on the inside. These tanks come in various shapes and the egg shape is gaining popularity with wine makers [6].

We are all, of course, familiar with the dreaded small plastic bottles of wine served on aeroplanes (coach class), and found in cafes and restaurants in art galleries, museums, some pubs, and theatres. Apart from the fact that wine tastes better the larger the container, I cannot understand how such foul-tasting liquid, masquerading as wine, is served in these bottles, when there is so much well-made wine available at reasonable prices.

Styrofoam (expanded polystyrene foam) is light and commonly used to transport bottles of wine. I recently took delivery of wines from Italy in Styrofoam containers and all bottles were intact. The main problem, however, is that Styrofoam is not recyclable. In December 2017 Kyle S. Spratt and his colleagues from the Applied Research Laboratories at the University of Texas at Austin, presented the result of their research to the annual meeting of the Acoustical Society of America in New Orleans showing that the bubbles generated from champagne consumed from a Styrofoam cup were larger than in champagne consumed from a glass. As small bubbles are associated with better champagne their results might be important. Who ever drinks Champagne from a Styrofoam cup? However, drinking beautiful Rosato (Rosé) from La Brancaia in Tuscany loses some of its charm when consumed on an overcast day in Dublin even from a well-made white wine glass.

Plastic cups, ubiquitous in America, release a substance called BPA (Bisphenol A) into the liquid contents. Some people believe that BPA is not advantageous to one's health. Recently a Russian friend, on her first visit to the USA, asked
Fig. 2 Harvesting bone marrow into plastic bags in $\mathrm{St}$ James' Hospital, Dublin. Courtesy Anthony Edwards, senior clinical photographer and Paul Quinlan, Medical Illustration Unit, St James' Hospital.

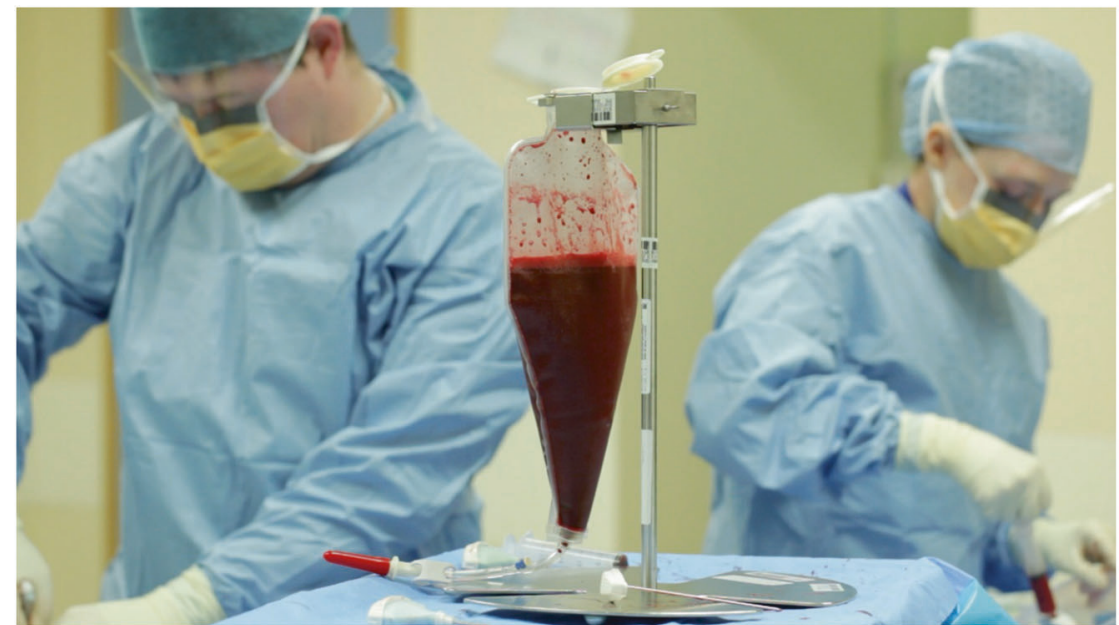




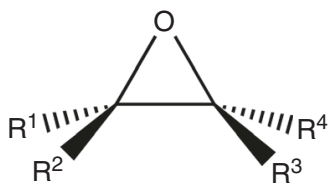

Fig. 3 Epoxide group. Epoxy resin can be used for manufacturing fermentation tanks but more often used to line cement tanks.

me, in amazement, what were all those people doing, walking around with plastic cups in their hands. I explained.

Recently a cardboard wine bottle has been launched. It is lighter than glass but, alas, has a plastic liner. I have only seen images of these bottles but expect they will have a huge aesthetic challenge to face in order to compete with glass bottles.

Whether you are drinking a glass of wine or receiving a blood transfusion, think of the amount of plastic waste and hope that clever scientists can design recyclable plastic. If you can afford it, travel in the front of the aeroplane (although air travel is now frowned upon by many people), where the wine is served from glass bottles into wine glasses.

\section{Compliance with ethical standards}

Conflict of interest The author declares that he has no conflict of interest.

Publisher's note Springer Nature remains neutral with regard to jurisdictional claims in published maps and institutional affiliations.

\section{References}

1. McCann SR. A history of haematology: from herodotus to HIV. Oxford: Oxford University Press; 2016.

2. Blundell J. Observations on blood transfusion. Lancet. $1829 ; 12: 321-4$.

3. Starr D. Blood: an epic history of medicine and commerce. 2000. New York: Quill.

4. Walter CW. Invention and development of the plastic bag. Vox Sang. 1984;47:318-24.

5. Gross A. Pandemic weakens global war on plastic waste. FT Weekend, 2020, July 25/26. London: The Financial Times Ltd.

6. McCann S. Can guidelines inhibit innovation and critical thinking. Bone Marrow Transplant. 2020. https://doi.org/10.1038/s41409020-0825-5. 